\title{
The antifungal effect of six commercial extracts of Chilean propolis on Candida spp.
}

\author{
Christian L. Herrera ${ }^{1,2}$, Marysol Alvear ${ }^{3}$, Leticia Barrientos ${ }^{1,4}$, \\ Gloria Montenegro ${ }^{5}$, and Luis A. Salazar ${ }^{1,4}$ \\ ${ }^{1}$ Departamento de Ciencias Básicas, and ${ }^{2}$ Departamento de Ciencias Preclínicas, Facultad de Medicina, \\ ${ }^{3}$ Departamento de Ciencias Químicas, Facultad de Ingeniería, Ciencias and Administración, and ${ }^{4}$ Núcleo de \\ Desarrollo Científico-Tecnológico en Biorecursos, Universidad de La Frontera. Casilla 54-D, Temuco, Chile. \\ ${ }^{5}$ Facultad de Agronomía e Ingeniería Forestal, Pontificia Universidad Católica de Chile, Casilla 306-22, \\ Santiago, Chile.
}

\begin{abstract}
C. L. Herrera, M. Alvear, L. Barrientos, G. Montenegro, and L. A. Salazar. 2010. The antifungal effect of six commercial extracts of Chilean propolis on Candida spp. Cien. Inv. Agr. 37(1): 75 - 84. Propolis has been used in traditional medicine for many centuries because of its beneficial health properties, including its antimicrobial capacity. Prosthesis stomatitis affects a significant percentage of users of removable dentures; Candida albicans is the most common fungal species associated with the development of this pathology. Thus, the objectives of this study were: a. To evaluate the antifungal activity of six commercial propolis extracts against Candida spp. that was isolated from the oral cavity of removable dentures users, and $\mathrm{b}$. To determine chemical characteristics of the propolis extracts evaluated. Among the results, we note that these concentrations of polyphenols varied between $9 \pm 0.3$ and $85 \pm$ $2.1 \mathrm{mg} \mathrm{mL}^{-1}$. Chromatographic analysis was able to detect 35 compounds, among which were caffeic acid, myricetin, quercetin, kaempferol, apigenin, pinocembrin, galangin, and caffeic acid phenyl ester (CAPE). All strains tested were inhibited by the liquid extracts of propolis. The MID ranged between 1:40 and 1:1280, and the MIC for C. albicans ranged from $197 \mu \mathrm{g}$ $\mathrm{mL}^{-1}$ to $441 \mu \mathrm{g} \mathrm{mL}^{-1}$. From the results obtained in this investigation, we can conclude that all propolis extracts evaluated are capable of inhibiting the development of Candida spp. However, they show significant differences in the concentration of polyphenols present and in antifungal activity.
\end{abstract}

Key words: Antifungal activity, Candida albicans, propolis.

\section{Introduction}

Propolis has been used in traditional medicine for centuries; however, its beneficial properties for human health have been explained scientifically only in recent decades.

Received 7 April 2009. Accepted 28 May 2009. Corresponding author: 1salazar@ufro.cl
It is well known that propolis composition shows great variability, both qualitatively and quantitatively, and its characteristics depend on botanical and geographical origin (Hegazi et al., 2000; Marcucci et al., 2000; Majiene et al., 2004; Peña, 2008). Salomao et al. (2004) states that the main components of an ethanolic extract of Brazilian propolis are aromatic acids, unlike Bulgarian propolis, which showed a predominance of flavonoids. 
This variable composition might be responsible for the differences observed in the biological activity detected in propolis with different origins (Cafarchia et al., 1999; Kujumgiev et al., 1999; Velikova et al., 2000). However, it is noteworthy to say that chemically different propolis, in some cases, shows similar biological activity (Salomao et al., 2004). Thus, beyond the activity of the individual components, the result is the consequence of a synergistic effect, which results in propolis having diverse pharmacological properties (Banskota et al., 2001; Kujumgiev et al., 1999). Currently, there is considerable scientific evidence showing not only their important role in the inflammatory response and cancer development but also their antioxidant activity and antimicrobial properties (Banskota et al., 2001; Burdock, 1998; Sforcin, 2007).

The antifungal activity of propolis has been specifically evaluated against different fungi. The genera Aspergillus (Aly and Elewa, 2007), Candida (Santos et al., 2005; Silici et al., 2005; O1iveira et al., 2006; Silici and Koc, 2006; Ghasem et al., 2007; Quintero-Mora et al., 2008;), Trichopyton (Koc et al., 2005; Siqueira et al., 2008), Trichosporon (Oliveira et al., 2006), Rhodotorula (Silici et al., 2005) and others have been analyzed regarding their susceptibility to propolis or to some of its components. These and other analyses have determined that pinocembrin, galangin and pinobanksin are the predominant compounds in the studied propolis (Hegazi et al., 2000; Uzel et al., 2005; Quiroga et al., 2006).

Yeasts of the genus Candida are part of the microbial flora of human beings; the skin and the mucosal membranes of airways, gastrointestinal and genito-urinary tract serve as their habitat. This genus may be found in $20 \%$ to $70 \%$ of the population. However, the incidence has increased due to the use of dentures, xerostomia, endocrine disorders, use of multiple antibiotics, use of immunodepressants, use of antineoplasics and other factors (Gonsalves et al., 2007).

Oral candidiasis is defined as an infection of the mucous membrane of the oral cavity caused by yeasts of the genus Candida. In users of remov- able dentures, $C$ albicans is the most common species associated with the development of subprosthestic stomatitis, the inflammation of oral mucous in contact with prosthesis. Dar-Odeth et al. (2003) found that C. albicans is responsible for $72 \%$ of the cases of subprosthestic stomatitis; although a variety of other species of this genus may also be responsible for this pathology (Pereira et al., 2008).

In recent years, the use of propolis has spread due not only to its beneficial properties but also to the emergence of propolis-supplemented food and cosmetics (Banskota et al., 2001). Although the consumption of alcoholic and non-alcoholic extracts of propolis has become popular in Chile, knowledge of the characteristics of these products is limited, unlike in other countries. According to different data bases, the study of the characteristics, composition and properties of Chilean propolis is restricted to a mere 12 scientific articles in the last ten years, and some type of biological activity has been evaluated only in four of them (Valcic et al., 1998; Valcic et al., 1999; Astudillo et al., 2000; Montenegro et al., 2000; Montenegro et al., 2001a; Montenegro et al., 2001b; Muñoz et al., 2001a; Muñoz et al., 2001b; Kumazawa et al., 2004; Montenegro et al., 2004; Russo et al., 2004; Hernández et al., 2005). Consequently, in addition to evaluating its botanical origin and chemical characteristics, Valcic et al. (1999) assessed its antimicrobial activity against Mycobacterium avium, M. tuberculosis and Staphylococcus aureus. Astudillo et al. (2000) evaluated its antioxidant activity, and Kumasawa et al. and Russo et al. (2004) evaluated its antioxidant and antitumoral activity, respectively.

Finally, with regard to the aforementioned studies, and to address the lack of studies evaluating the activity of the Chilean propolis against $\mathrm{Can}$ dida spp., the objectives of the present study were: a. To evaluate the antifungal activity of six commercial extracts of propolis on Candida spp. strains that were isolated from the oral cavity of removable dental prosthesis users and $b$. To determine some of the chemical characteristics of the propolis extracts. 


\section{Materials and methods}

\section{Propolis samples}

Six liquid extracts of propolis (mother tincture) were purchased from drugstores and stores of natural products in Temuco, Chile.

\section{Microorganisms}

The strains of Candida spp. used in this study were isolated from the oral cavity of removable dental prosthesis users from Temuco, Chile. The study protocol was approved by the Ethics Committee of the Universidad de La Frontera, and all subjects gave written, informed consent according to the basic principles of biomedical investigation enumerated in the Helsinki Declaration.

The isolation and identification of the microbial species were conducted in the Laboratory of Molecular Biology and Pharmacogenetics of Universidad de La Frontera, Temuco, Chile. For $C$. albicans, identification was made using CHROMagar Candida (Laboratorios Linsan S.A., Chile), the germinal tube formation test and Polymerase Chain Reaction (PCR). The primers used and conditions of reaction were previously described by Baquero et al. (2002). Identification by PCR of C. albicans strains is shown in Figure 1. In addition, the identification of $C$. dubliniensis, which presents phenotypical characteristics similar to that of $C$. albicans, was evaluated by monitoring development at $45^{\circ} \mathrm{C}$ in Sabouraud dextrose agar (Sharlau, Spain) (Pinjon et al., 1998), and by PCR-restriction fragment length polymorphism (PCR-RFLP), using the restriction endonuclease $B \ln \mathrm{I}$ (Fermentas, Lithuania) (Mirhendi et al., 2005). Other species of the genus Candida were identified through the use of CHROMagar Candida.

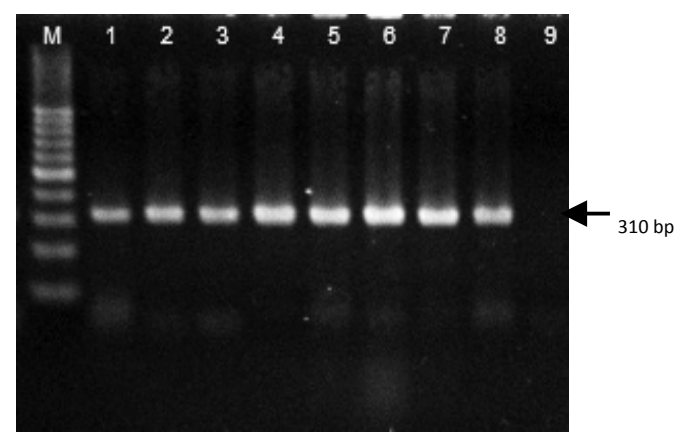

Figure 1. PCR products of Candida albicans identification. Agarose gel (2\%), stained with ethidium-bromide. M: molecular weight marker, lanes 1-8: clinical samples, lane 9: negative control.

\section{Total polyphenols}

The Folin-Ciocalteu method was used to determine the total polyphenol content of the extracts evaluated (Singleton et al., 1999). Briefly, each extract was diluted 1:10 in 70\% ethanol and then 1:10 in distilled water. Subsequently, $40 \mu \mathrm{l}$ of this dilution was mixed with $560 \mu \mathrm{l}$ of distilled water, $100 \mu \mathrm{l}$ of the Folin-Ciocalteu reagent (Merck, Germany) and $300 \mu \mathrm{l}$ of $7.5 \%$ sodium carbonate $(\mathrm{w} / \mathrm{v})$. The absorbance was measured at $760 \mathrm{~nm}$ after $2 \mathrm{~h}$ of incubation at room temperature. The concentrations were calculated from a calibration curve and were expressed in $\mathrm{mg} \mathrm{mL}^{-1}$ equivalent to the mixture of the pinocembrin:galangin standards in a $2: 1$ ratio (Popova et al., 2007). All measurements were made three times.

\section{Chromatographic analysis}

High performance liquid chromatographic (HPLC) analysis was made on an HPLC system (Merck-Hitachi model L-4200) equipped with a pump (model L-6200), a UV-visible detector and a Sphere Column Heater (Phenomenex Terma model TS-130). The separation was made in an RP-18 column $(12.5 \times 0.4 \mathrm{~cm}$, particle size 
$5 \mu \mathrm{m}$ ) (Merck, Germany), which separates at $25^{\circ} \mathrm{C}$ using a mixture of formic acid 5\% in water (A) and methanol (B) as mobile phase. The separation of the compounds was carried out by an isocratic- 0 to 10 min-run, with the mixture $70 \% \mathrm{~A}$ and $30 \% \mathrm{~B}$, followed by a gradient up to $100 \%$ B at $70 \mathrm{~min}$. The compounds were detected at $290 \mathrm{~nm}$, with 0.001 sensitivity; the injection volume was $10 \mu \mathrm{L}$. The identification of the phenolic compounds was made using the following standards: myricetin, kaempferol, quercetin, caffeic acid, galangin, pinocembrin, apigenin, caffeic acid phenyl ester (CAPE) and resveratrol (Sigma, USA).

\section{Antifungal activity of propolis}

The minimum inhibitory dilution (MID) and the minimum inhibitory concentration (MIC) were determined by the broth microdilution method following the standards of the National Committee for Clinical Laboratory Standards (NCCLS, 1997) with some modifications. The culture medium used for this test was RPMI1640 broth with L-glutamine, which was supplemented with glucose at $2 \%$ and buffered with morpholine-propanosulphonic acid (MOPS) at pH 7.0 (Silva et al., 2003).

The yeast suspensions were prepared in sterile physiological serum at a concentration of 1.5 x $10^{6} \mathrm{cfu} \mathrm{mL}^{-1}$. The absorbance of this suspension was determined by spectrophotometry and was compared to the MacFarland standard. This suspension was diluted (1:50) in sterile physiological serum and then in the culture medium (1:20) to obtain a final concentration of $0.75 \mathrm{x}$ $10^{3} \mathrm{cfu} \mathrm{mL}^{-1}$ in the culture plate.

The commercial extracts of propolis were diluted serially in the culture plate to obtain dilutions varying from 1:10 to 1:2560 and to obtain ethanol proportions varying from 7 to $0.03 \%$, respectively. Positive, negative and solvent controls were conducted for all conditions.

Plates were incubated for $48 \mathrm{~h}$ at $37^{\circ} \mathrm{C}$, and the results were determined by the presence or absence of microorganism development in a specific propolis dilution. The MICs were determined as the lowest propolis concentration where a microbial development was not observed, and the MID was determined as the lowest propolis dilution where a microbial development was not observed.

\section{Statistical analysis}

Averages, standard deviations, and maximum and minimum values were calculated when necessary. Analysis of variance (ANOVA) was used for comparing the chosen level of statistical significance and was $\mathrm{p}<0.05$. The data analysis was made using the program GraphPad Prism, version 3.0 (Graphpad Software, San Diego, CA, USA).

\section{Results}

\section{Microorganisms}

For the evaluation of antifungal activity of the propolis extracts, a total of 21 isolates were used: C. albicans (18), C. tropicalis (2) and $C$. glabrata (1). The PCR identification of C. albicans is shown in Figure 1.

\section{Total polyphenols}

The propolis extracts evaluated showed considerable differences in concentration of total polyphenols, with almost a 10 -fold difference between the highest and the lowest concentration obtained. In addition, no relation between the concentrations determined in this study and the propolis concentration declared by the manufacturers was found (Table 1).

\section{Chromatographic analysis}

The chromatographic analysis of the propolis samples detected 35 compounds in sample I (Figure 2), which was the largest number of 
Table 1. Total polyphenol content in extracts of commercial Chilean propolis. Method: Folin-Ciocalteu.

\begin{tabular}{ccc}
\hline $\begin{array}{c}\text { Propolis extract } \\
\text { Propolis concentration } \\
\%\end{array}$ & $\begin{array}{c}\text { Total polyphenols }^{2} \\
\mathrm{mg} \mathrm{mL}^{-1}\end{array}$ \\
\hline I & 20 & $85 \pm 2.1$ \\
II & 10 & $9 \pm 0.3$ \\
III & 20 & $41 \pm 0.4$ \\
IV & nd & $16 \pm 0.2$ \\
V & nd & $19 \pm 0.9$ \\
VI & 20 & $16 \pm 0.4$ \\
\hline${ }^{1}$ Propolis concentration & declared by & manufacturers. \\
nd: Not determined. &
\end{tabular}

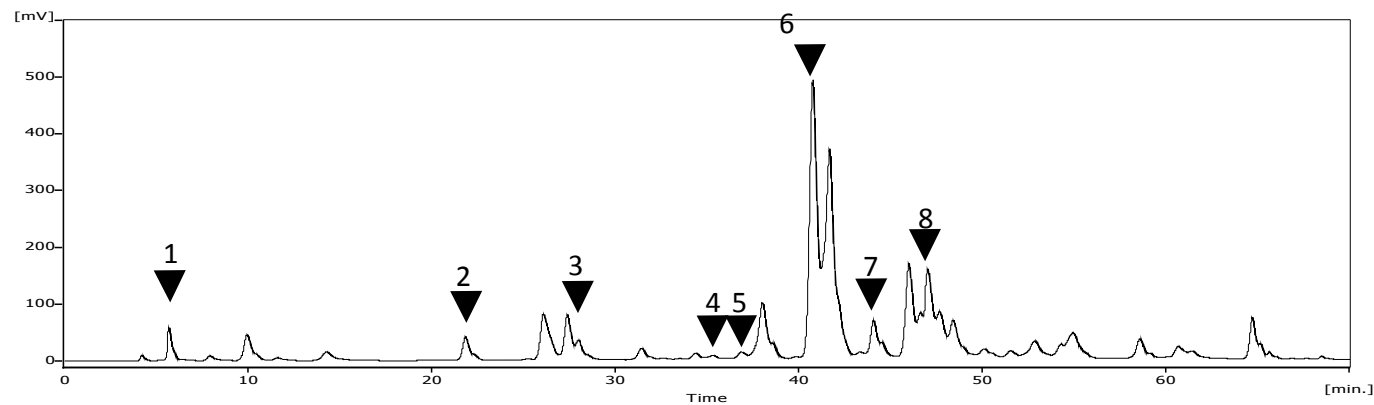

Figure 2. Chromatographic pattern of commercial extract I of Chilean propolis. Wavelength: $290 \mathrm{~nm}$. Injection volume: $10 \mu \mathrm{L}$. Identified compounds: 1, caffeic acid; 2, myricetin; 3, quercetin; 4, kaempherol; 5, apigenin; 6, pinocembrin; 7, galangin; 8, caffeic acid phenyl ester (CAPE).

compounds detected. On the other hand, only seven compounds were detected in sample II. Regardless of these differences, all the samples had similar chromatographic patterns, with pinocembrin being one of the predominant compounds in these propolis extracts.

\section{Antifungal activity}

It was determined that all propolis samples inhibited the development of the tested strains of Candida spp. However, there were important differences in extract dilutions that showed inhibition of Candida spp. (Table 2). For C. albicans, a 1:320 dilution had the highest MID with propolis I, while a 1:40 dilution of propolis II and $\mathrm{V}$ produced the highest MID. A similar result was obtained with C. tropicalis. Also, in the case of $C$. glabrata, the propolis with the high- est and lowest activity was the same, but the inhibition was observed at higher dilutions.

In the case of $C$. albicans, when comparing the respective concentrations for dilutions inhibiting development, significant differences were observed in propolis extracts IV and VI, which were active at lower concentrations, compared with propolis extracts I, III and V, which were active at higher concentrations.

\section{Discussion}

The evaluation of the biological activity of propolis, particularly its antifungal activity, has been studied previously (Sawaya et al., 2002; Santos et al., 2005; Silici and Kutluca, 2005; Silici et al., 2005; Oliveira et al., 2006; Ghasem et al., 2007; Quintero-Mora et al., 2008). However, the information obtained 
Table 2. Minimum inhibitory dilution (MID) ${ }^{1}$ and minimum inhibitory concentration (MIC) of commercial Chilean propolis on Candida spp.

\begin{tabular}{|c|c|c|c|c|c|c|}
\hline \multirow[b]{2}{*}{ Propolis extracts } & \multicolumn{2}{|c|}{ C. albicans } & \multicolumn{2}{|c|}{ C. tropicalis } & \multicolumn{2}{|c|}{ C. glabrata } \\
\hline & MID & $\begin{array}{c}\mathrm{MIC} \\
\mu \mathrm{g} \mathrm{ml}^{-1}\end{array}$ & MID & $\begin{array}{c}\mathrm{MIC} \\
\mu \mathrm{g} \mathrm{ml}^{-1}\end{array}$ & MID & $\begin{array}{c}\mathrm{MIC} \\
\mu \mathrm{g} \mathrm{ml}^{-1}\end{array}$ \\
\hline I & 6 & $287 \pm 93$ & 6 & 265 & 8 & 66 \\
\hline II & 3 & $224 \pm 74$ & 3 & 227 & 4 & 113 \\
\hline III & 5 & $324 \pm 117$ & 5 & 253 & 5 & 253 \\
\hline IV & 4 & $197 \pm 59$ & 4 & 197 & 5 & 99 \\
\hline $\mathrm{V}$ & 3 & $441 \pm 103$ & 3 & 476 & 5 & 119 \\
\hline VI & 4 & $198 \pm 65$ & 4 & 204 & 6 & 51 \\
\hline
\end{tabular}

${ }^{1}$ MID 1=1:10; MID 2=1:20; MID 3=1:40; MID 4=1:80; MID 5=1:160; MID 6=1:320; MID 7=1:640; MID 8=1:1280. For C. albicans, MID values are expressed by mode.

in this research is needed in Chile because of unique propolis characteristics and the dependence of its chemical/biological characteristics on its botanical origin.

Bankova (2005) states that, as the concentration and activity of the components of different propolis extracts are unknown, it is necessary to consider each extract as an active principle in itself. On this basis, not only were the concentrations of total polyphenols in propolis extracts determined, but important differences in the concentrations of active compounds were also found; this is relevant because the concentration, in part, establishes the degree of the extracts's biological activity. This relevance was evident when the samples with significant differences expressed in MID (propolis I and II: $1 / 320$ and $1 / 40$, respectively) showed no difference when compared to the MIC (propolis I and II: $287 \pm 93$ and $224 \pm 74 \mu \mathrm{g} \mathrm{mL}^{-1}$, respectively).

Chromatographic analysis detected at least 35 compounds in propolis I and identified caffeic acid, myricetin, quercetin, kaempferol, apigenin, pinocembrin, galangin and caffeic acid phenyl ester (CAPE). Regardless of the differences in the number of compounds detected among the samples analyzed, the chromatographic profiles exhibited great similarities. Differences were mainly associated with compound concentration differences.
The activity of propolis on $C$. albicans has been evaluated by different methodologies (e.g., agar dilution, agar diffusion, macro and microdilution broth). Due to variations both in the methodologies used and in the modes of determining the concentration of active substances, comparing the results from different studies becomes difficult. For example, throught broth microdilution, Oliveira et al. (2006) showed that a concentration of $50 \mu \mathrm{g} \mathrm{mL}^{-1}$ of total flavonoids was able to inhibit the development of 67 onychomycosis fungal species; specifically, the $\mathrm{MIC}_{90}$

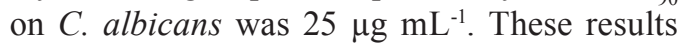
are different from those informed by Sawaya et al. (2002), who determined that the MIC on C. albicans varied between 6 and $12 \mu \mathrm{g} \mathrm{mL}^{-1}$ using agar dilution. In addition, these researchers could not obtain satisfactory results by broth macrodilution and agar diffusion.

In our study, it was observed that all propolis samples evaluated were able to inhibit the development of Candida spp., although differences were observed regarding the MIC; ranging between $278 \mu \mathrm{g} \mathrm{mL}^{-1}$ for C. albicans and $117 \mu \mathrm{g} \mathrm{mL}^{-1}$ for C. glabrata.

Currently, subprosthesis stomatitis arises as a real problem for an important number of users of removable dentures. Infection by C. albicans is clearly identified as one of the main predisposing factors in its development (Baena-Monroy et al., 2005; de Resende et al., 2006; Bilhan 
et al., 2008). The evaluated propolis demonstrated antifungal activity; but there is a new possibility for Chilean propolis to be used in the elaboration of products that prevent and/or treat subprosthesis stomatitis. An experience of this kind, conducted in Brazil showed that patients with subprosthesis stomatitis and treated with an ethanolic extract of propolis obtained a similar effect when compared with a group of patients treated with nystatin; however, the number of patients considered in that study was small (Santos et al., 2005).

Although many products in the Chilean market are supplemented with or based on propolis, the results obtained in this research show that the extracts of propolis studied were not equivalent in relation to the concentration of total polyphenols. These results show the need for regulation both in determining the geographical and botanical origin of propolis as well as in determining the chemical characterization of extracts. Therefore, a clear standardization of characteristics of this product and knowledge of its composition are needed to extrapolate from composition to particular biological properties. These practices would not only add value to the national propolis, but it would also allow the population to choose and use products with known characteristics, as appointed by Peña (2008).

In summary, all of the propolis samples evaluated in this study have the ability to inhibit the development of Candida spp. since their qualitative characteristics are similar; however, they show important differences both in the concentration of polyphenols present and in antifungal activity.

\section{Acknowledgements}

This study was supported by grants from Dirección de Investigación y Desarrollo (DIDUFRO INI 110605) Universidad de La Frontera, and CONICYT (FONDEF D05I-10021), Chile.

\section{Resumen}

C. L. Herrera, M. Alvear, L. Barrientos, G. Montenegro y L. A. Salazar. 2010. The antifungal effect of six commercial extracts of Chilean propolis on Candida spp. Cien. Inv. Agr. 37(1): 75- 84. El propóleo ha sido utilizado por la medicina tradicional desde hace muchos siglos debido a sus propiedades benéficas para la salud, entre las que destaca su capacidad antimicrobiana. La estomatitis subprotésica, afecta a un porcentaje importante de usuarios de prótesis dental removible, siendo Candida albicans la especie fúngica más común asociada al desarrollo de esta patología. Así, los objetivos de este estudio fueron: a) evaluar la actividad antifúngica de seis extractos de propóleos comerciales sobre cepas de Candida spp. aisladas de la cavidad oral de usuarios de prótesis dental removible, y b) determinar algunas características químicas de los extractos de propóleos utilizados. Entre los resultados obtenidos, podemos señalar que éstos mostraron concentraciones de polifenoles que variaron entre $9 \pm 0,3$ y $85 \pm$ $2,1 \mathrm{mg} / \mathrm{mL}$. El análisis cromatográfico permitió detectar 35 compuestos, entre los cuales se logró identificar la presencia de ácido cafeico, miricetina, quercetina, kaempferol, apigenina, pinocembrina, galangina y ácido cafeico fenil éster (CAPE). Todas las cepas de Candida spp. evaluadas fueron inhibidas por los seis extractos líquidos de propóleos, observándose que la DIM varió entre $1 / 40$ y 1/1280, y la CIM para C. albicans varió entre $197 \mu \mathrm{g} / \mathrm{mL}$ y $441 \mu \mathrm{g} /$ $\mathrm{mL}$. A partir de los resultados obtenidos en esta investigación podemos concluir que todos los propóleos evaluados son capaces de inhibir el desarrollo de Candida spp., sin embargo, éstos muestran importantes diferencias en la concentración de los polifenoles presentes y en la actividad antifúngica.

Palabras claves: Actividad antifúngica, Candida albicans, propóleos. 


\section{References}

Aly, S.A., and N.A. Elewa. 2007. The effect of Egyptian honeybee propolis on the growth of Aspergillus versicolor and sterigmatocystin biosynthesis in Ras cheese. J. Dairy Res. 74:74-8.

Astudillo, S., L.R. Avila, F.R. Morrison, M. Gutiérrez, J. Bastida, C. Codina, and G. Schmeda-Hirschmann. 2000. Biologically active compounds from Chilean propolis. Bol. Soc. Chil. Quím. 45:577-581.

Baena-Monroy, T., V. Moreno-Maldonado, F. Franco-Martínez，B. Aldape-Barrios, G. Quindos, and L.O. Sánchez-Vargas. 2005. Candida albicans, Staphylococcus aureus and Streptococcus mutans colonization in patients wearing dental prosthesis. Med. Oral Patol. Oral Cir. Bucal 10 Suppl. 1:E27-39.

Bankova, V. 2005. Chemical diversity of propolis and the problem of standardization. J. Ethnopharmacol. 100:114-117.

Banskota, A.H., Y. Tezuka, and S. Kadota. 2001. Recent progress in pharmacological research of propolis. Phytotherapy Research 15:561-571.

Baquero, C., M. Montero, R. Sentandreu, and E. Valentin. 2002. Identificación de Candida albicans por amplificación del intrón del gen CaYST1 mediante reacción en cadena de la polimerasa. Rev. Iberoam. Micol. 19:80-83.

Bilhan, H., T. Sulun, G. Erkose, H. Kurt, Z. Erturan, O. Kutay, and T. Bilgin. 2008. The role of Candida albicans hyphae and Lactobacillus in denturerelated stomatitis. Clin. Oral Investig.

Burdock, G.A. 1998. Review of the biological properties and toxicity of bee propolis (propolis). Food Chem. Toxicol. 36:347-63.

Cafarchia, C., N. de Laurentis, M.A. Milillo, V. Losacco, and V. Puccini. 1999. Antifungal activity of Apulia region propolis. Parassitologia 41:58790.

Dar-Odeh, N.S., and A.A. Shehabi. 2003. Oral candidiasis in patients with removable dentures. Mycoses 46:187-91.

de Resende, M.A., L.V. de Sousa, R.C. de Oliveira, C.Y. Koga-Ito, and J.P. Lyon. 2006. Prevalence and antifungal susceptibility of yeasts obtained from the oral cavity of elderly individuals. Mycopathologia 162:39-44.

Ghasem, Y.B., A. Ownagh, and M. Hasanloei. 2007. Antibacterial and antifungal activity of Iranian propolis against Staphylococcus aureus and Candida albicans. Pak. J. Biol. Sci. 10:1343-5.

Gonsalves, W.C., A.C. Chi, and B.W. Neville. 2007. Common oral lesions: Part I. Superficial mucosal lesions. Am. Fam. Physician. 75:501-7.

Hegazi, A.G., F.K. Abd El Hady, and F.A. Abd Allah. 2000. Chemical composition and antimicrobial activity of European propolis. Z. Naturforsch. [C] 55:70-5.

Hernández, M.S., C.S. Lazo, J.M. Junod, J.M. Arancibia, R.S. Flores, A.E. Valencia, and E.V. Valenzuela. 2005. Organoleptic and physicochemical characteristics of propolis in the Province of Ñuble, VIII Región-Chile. Arch. Latinoam. Nutr. 55:374-9.

Koc, A.N., S. Silici, D. Ayangil, A. Ferahbas, and S. Cankaya. 2005. Comparison of in vitro activities of antifungal drugs and ethanolic extract of propolis against Trichophyton rubrum and $T$. mentagrophytes by using a microdilution assay. Mycoses 48:205-10.

Kujumgiev, A., I. Tsvetkova, Y. Serkedjieva, V. Bankova, R. Christov, and S. Popov. 1999. Antibacterial, antifungal and antiviral activity of propolis of different geographic origin. J. Ethnopharmacol. 64:235-40.

Kumazawa, S., T. Hamasaka, and T. Nakayama. 2004. Antioxidant activity of propolis of various geographic origins. Food Chemistry 84:329339.

Majiene, D., S. Trumbeckaite, D. Grunoviene, L. Ivanauskas, and A. Gendrolis. 2004. Investigation of chemical composition of propolis extract. Medicina (Kaunas) 40:771-4.

Marcucci, M.C., F. Ferreres, A.R. Custodio, M.M. Ferreira, V.S. Bankova, C. García-Viguera, and W.A. Bretz. 2000. Evaluation of phenolic compounds in Brazilian propolis from different geographic regions. Z. Naturforsch. [C] 55:76-81.

Mirhendi, H., K. Makimura, K. Zomorodian, N. Maeda, T. Ohshima, and H. Yamaguchi. 2005. Differentiation of Candida albicans and Candida dubliniensis using a single-enzyme PCR-RFLP method. Jpn. J. Infect. Dis. 58:235-7.

Montenegro, G., G. Avila, and R.C. Peña. 2001a. Botanical origin and seasonal production of propolis in hives of Central Chile. Bol. Bot. Univ. Sao Paulo 19:1-6.

Montenegro, G., R.C. Peña, A. Mujica, and R. Pizarro. 2001b. Botanical resources for propolis in an apiary network in central Chile. Phyton 69:191201. 
Montenegro, G., B.N. Timmermann, R.C. Peña, A. Mujica, and G. Avila. 2000. Pollen grains and vegetative structures in propolis as indicators of potential drugs in Chilean plants. Phyton 66:1523.

Montenegro, G., A.M. Mujica, R.C. Peña, M. Gómez, I. Serey, and B.N. Timmermann. 2004. Similitude pattern and botanical origin of the Chilean propolis. Phyton 73:145-154.

Muñoz, O., R.C. Peña, E. Ureta, G. Montenegro, and B.N. Timmermann. 2001a. Propolis from Chilean matorral hives. Z. Naturforsch [C]. 56:269-72.

Muñoz, O., R.C. Peña, E. Ureta, G. Montenegro, C. Caldwell, and B.N. Timmermann. 2001b. Phenolic compounds of propolis from Central Chilean matorral. Z Naturforsch [C] 56:273-7.

Oliveira, A.C., C.S. Shinobu, R. Longhini, S.L. Franco, and T.I. Svidzinski. 2006. Antifungal activity of propolis extract against yeasts isolated from onychomycosis lesions. Mem. Inst. Oswaldo Cruz 101:493-7.

Peña, R.C. 2008. Estandarización en propóleos: antecedentes químicos y biológicos. Ciencia e Investigación Agraria 35:17-26.

Pereira, T., A.A. del Bel Cury, W. Crielaard, and J.M. Ten Cate. 2008. Development of Candida-associated denture stomatitis: new insights. J. Appl. Oral Sci. 16:86-94.

Pinjon, E., D. Sullivan, I. Salkin, D. Shanley, and D. Coleman. 1998. Simple, inexpensive, reliable method for differentiation of Candida dubliniensis from Candida albicans. J Clin. Microbiol. 36:2093-5.

Popova, M.P., V. Bankova, S. Bogdanov, I. Tsvetkova, C. Naydenski, G.L. Marcazzan, and A.G. Sabatini. 2007. Chemical characteristics of poplar type propolis of different geographic origin. Apidologie 38:306.

Quintero-Mora, M.L., A. Londoño-Orozco, F. Hernández-Hernández, P. Manzano-Gayosso, R. López-Martínez, C.I. Soto-Zárate, L. Carrillo-Miranda, G. Penieres-Carrillo, C.G. GarcíaTovar, and T.A. Cruz-Sánchez. 2008. Effect of Mexican propolis extracts from Apis mellifera on Candida albicans in vitro growth. Rev. Iberoam. Micol. 25:22-6.

Quiroga, E.N., D.A. Sampietro, J.R. Soberon, M.A. Sgariglia, and M.A. Vattuone. 2006. Propolis from the northwest of Argentina as a source of antifungal principles. J. Appl. Microbiol. 101:103-10.

Russo, A., V. Cardile, F. Sánchez, N. Troncoso, A.
Vanella, and J.A. Garbarino. 2004. Chilean propolis: antioxidant activity and antiproliferative action in human tumor cell lines. Life Sci. 76:545-58.

Salomao, K., A.P. Dantas, C.M. Borba, L.C. Campos, D.G. Machado, F.R. Aquino Neto, and S.L. de Castro. 2004. Chemical composition and microbicidal activity of extracts from Brazilian and Bulgarian propolis. Lett. Appl. Microbiol. 38:8792.

Santos, V.R., F.J. Pimenta, M.C. Aguiar, M.A. do Carmo, M.D. Naves, and R.A. Mesquita. 2005. Oral candidiasis treatment with Brazilian ethanol propolis extract. Phytother. Res. 19:652-664.

Sawaya, A.C., A.M. Palma, F.M. Caetano, M.C. Marcucci, I.B. da Silva Cunha, C.E. Araujo, and M.T. Shimizu. 2002. Comparative study of in vitro methods used to analyse the activity of propolis extracts with different compositions against species of Candida. Lett. Appl. Microbiol. 35:203-207.

Sforcin, J.M. 2007. Propolis and the immune system: a review. J Ethnopharmacol 113:1-14.

Silici, S., and S. Kutluca. 2005. Chemical composition and antibacterial activity of propolis collected by three different races of honeybees in the same region. J. Ethnopharmacol. 99:69-73.

Silici, S., and A.N. Koc. 2006. Comparative study of in vitro methods to analyse the antifungal activity of propolis against yeasts isolated from patients with superficial mycoses. Lett. Appl. Microbiol. 43:318-24.

Silici, S., N.A. Koc, D. Ayangil, and S. Cankaya. 2005. Antifungal activities of propolis collected by different races of honeybees against yeasts isolated from patients with superficial mycoses. J. Pharmacol. Sci. 99:39-44.

Silva, V., M. Cabrera, M.C. Díaz, C. Abarca, and G. Hermosilla. 2003. Prevalence of Candida albicans serotypes in blood isolates in Chile, and first report of Candida dubliniensis candidemia. Rev. Iberoam. Micol. 20:46-51.

Singleton, V.L., R. Orthofer, R.M. LamuelaRavento's. 1999. Analysis of total phenols and other oxidation substrates and antioxidants by means of Folin-Ciocalteu reagent. Methods Enzymol. 299:152-178.

Siqueira, A.B., B.S. Gomes, I. Cambuim, R. Maia, S. Abreu, C.M. Souza-Motta, L.A. de Queiroz, and A.L. Porto. 2009. Trichophyton species susceptibility to green and red propolis from Brazil. Lett. Appl. Microbiol. 48:90-96. 
Uzel, A., K. Sorkun, O. Oncag, D. Cogulu, O. Gencay, and B. Salih. 2005. Chemical compositions and antimicrobial activities of four different Anatolian propolis samples. Microbiol. Res. 160:189-95.

Valcic, S., G. Montenegro, and B.N. Timmermann. 1998. Lignans from Chilean propolis. J. Nat. Prod. 61:771-775.

Valcic, S., G. Montenegro, A.M. Mujica, G. Avila, S. Franzblau, M.P. Singh, W.M. Maiese, and B.N.
Timmermann. 1999. Phytochemical, morphological, and biological investigations of propolis from Central Chile. Z. Naturforsch. [C] 54:40616.

Velikova, M., V. Bankova, M.C. Marcucci, I. Tsvetkova, and A. Kujumgiev. 2000. Chemical composition and biological activity of propolis from Brazilian meliponinae. Z. Naturforsch. [C] 55:785-9. 